\title{
The organizational mechanism for the formation of programs for the renovation of cultural heritage objects on the basis of the value approach
}

\author{
Vera Akristiniy ${ }^{1, *}$ \\ ${ }^{1}$ Moscow State University of Civil Engineering, Yaroslavskoe shosse, 26, Moscow, 129337, Russia
}

\begin{abstract}
The article discusses the issues of preservation of cultural heritage objects due to their mass loss by creating a mechanism for the efficient selection of objects subject to renovation. The algorithm for the calculation of the degree of deterioration of the building and the integral index of value is proposed. The problem of definition of the objective function with respect to which is characterized by the objective function of the optimal feature set and the problem of definition of the target functions of state programs of renovation are solving preservation.
\end{abstract}

\section{Introduction}

Preservation of objects of a cultural heritage of cities and regions is one of the major state and public tasks fixed in the legislative acts of the Russian Federation. The cultural heritage of our country, which has a centuries-old history, is very extensive and diverse. Currently, over 90,000 monuments are on state protection, of which about a quarter - 23397 - are monuments of federal significance. 15 unique sites are included in the UNESCO List of World Cultural and Natural Heritage [6].

However, this global wealth, which is the pride of our country, is currently experiencing a number of serious threats. The long absence of system solutions, the obsolete production, regulatory and educational bases for preserving monuments do not meet modern requirements and tasks [1].

\section{Architectural and construction sector indicators}

The situation with the preservation of the cultural heritage is extraordinary: only $10-15 \%$ of the monuments are in a satisfactory condition, about $2 / 3$ of the total number of cultural heritage sites need urgent measures to save them from destruction. Over the past 5 years, about 10,000 monuments have died, and this figure is almost not reduced (Table 1).

\footnotetext{
*Corresponding author: 7824666@mail.ru
} 
Table 1. The number of immovable monuments of history and culture

\begin{tabular}{|l|c|c|c|c|c|c|}
\hline & 2000 & 2005 & 2010 & 2011 & 2012 & 2013 \\
\hline $\begin{array}{l}\text { number of immovable } \\
\text { monuments of history } \\
\text { and culture }\end{array}$ & 84900 & 87800 & 143400 & 185100 & 175900 & 180100 \\
\hline including: & - & 18100 & 36500 & 78000 & 78900 & 82200 \\
\hline $\begin{array}{l}\text { monuments of } \\
\text { archaeological }\end{array}$ & 24100 & 36100 & 31100 & 29400 & 30700 \\
\hline monuments of history & - & 42700 & 66800 & 70100 & 61800 & 61400 \\
\hline $\begin{array}{l}\text { monuments of urban } \\
\text { development and } \\
\text { architecture }\end{array}$ & - & 2900 & 4000 & 4900 & 3700 & 4100 \\
\hline works of art & - & & & & & \\
\hline
\end{tabular}

Source: Rosstat

More than half of all monuments are in unsatisfactory and often in emergency condition and require urgent emergency response or conservation work. At the same time passportization and monitoring of the state of historical and cultural monuments are conducted in insufficient volume [2].

Strengthening of negative factors in the international economy leaves the urgent task of attracting extra-budgetary investments for the preservation and restoration of monuments. But their large-scale attraction is possible only after the terms of the security obligations have been determined for each object, the procedure for access to them by citizens has been established. Currently, the main investor in the preservation of monuments is the state and in the near future such will remain [3-5].

\section{Methodology for a comprehensive assessment of the technical condition of the object}

When creating state programs for the preservation of cultural heritage objects, there arises a problem of prioritizing the choice of objects that are subject to priority measures for their renovation. The number of destroying monuments of historical heritage is quite large with limited financial resources allocated for the implementation of conservation programs, in connection with which the solution of this problem is the most urgent problem for now $[5,11]$.

The task of forming a rational set of buildings-monuments that are to be saved is reduced to the fact that out of all their set, it is required to select a number of objects of greatest value. In this case, the maximum possible effect will be a set of objects that, at high values of value, will have the least amount of depreciation, what precedes the priority for renovation of these objects.

The main criterion for assessing the technical condition of buildings, their elements and engineering systems is physical deterioration - the loss of their initial technical and operational qualities as a result of the impact of natural-climatic and anthropogenic factors. A sign of permanent physical deterioration is that further operation of the building becomes unacceptable under the conditions of ensuring the requirements for the safe operation of facilities.

In the case of particularly valuable buildings - monuments of cultural heritage, the stage of permanent physical depreciation is unacceptable, since one of the main principles of preserving such objects is to ensure the maximum possible lifespan. The factor that must be taken into account in the integrated assessment of the state of monuments is the need to ensure 
their unlimited life cycle, i.e. Inadmissibility of an emergency. The value of objects of cultural heritage is determined by the authenticity of structures and materials of the historical era, as well as by selective valuable layers that they acquired during life, and the loss of even a small fragment of a unique object is critical. Therefore, the calculation of wear must be carried out separately for each element and maintain their state within the acceptable limits of satisfactory physical deterioration. Existing methods [16] are systematized in the structural scheme of determining the degree of deterioration $\tau_{\text {det }}$ of buildings - monuments of cultural heritage (Figure 1).

\begin{tabular}{|c|c|c|}
\hline $\begin{array}{l}\text { Building, whose life is above } \\
\text { the legal }\end{array}$ & $\begin{array}{l}\text { Building, whose life did not } \\
\text { exceed regulatory }\end{array}$ & $\begin{array}{l}\text { Depreciation of engineering } \\
\text { networks and landscaping elements }\end{array}$ \\
\hline$\downarrow$ & 1 & $I$ \\
\hline $\begin{array}{l}\text { PHYSICAL DETERIORATION ON } \\
\text { THE ACTUAL TECHNICAL } \\
\text { CONDITION } \\
\qquad P D_{c}=\sum_{i=1}^{n} P D_{i} * R_{i} / R_{k} \\
P D_{i}-\text { physical deterioration of } \\
\text { the i-th section of the element or } \\
\text { system, \%; } \\
R i-\text { size (area or length) of the i- } \\
\text { th area, } \mathrm{m} 2 \text { or } \mathrm{m} \text {; } \\
R k-\text { size of the structural } \\
\text { element or system, m2 or m; } \\
n-\text { number of damaged areas. }\end{array}$ & $\begin{array}{l}\text { SERVICE LIFE OF THE } \\
\text { STRUCTURAL ELEMENT } \\
\qquad P D_{c}=\sum_{i=1}^{n} P D_{i} * k_{i} \\
P D_{i}-\text { physical deterioration of the } \\
\text { material layer defined by the VSN } \\
53-86(\mathrm{R}) \text { depending on the } \\
\text { lifetime of the layered structure, } \\
\% \text {; } \\
K_{i}-\text { factor, defined as the ratio of } \\
\text { the value of the layer material to } \\
\text { the cost of the whole structure; } \\
n-\text { number of layers. }\end{array}$ & $\begin{array}{l}\text { ON THE INTEGRATED INDICATORS } \\
\quad \text { OF REGENERATIVE COST } \\
\qquad P D_{E N}=\sum_{i=1}^{n} P D_{i} * l_{i} \\
P D_{E N} \text { - physical deterioration of } \\
\text { engineering systems, \%; } \\
P D i-\text { deterioration of separate } \\
\text { system, \%; } \\
l i-\text { coefficient corresponding to the } \\
\text { proportion of the replacement cost of } \\
\text { separate systems for a total } \\
\text { replacement cost; } \\
n \text { - number of individual engineering } \\
\text { systems. }\end{array}$ \\
\hline $\begin{array}{l}\text { где } P_{\text {det(limit }} \text { - proportion of structu } \\
\text { allowable values for particular typ } \\
P_{o b j}-\text { total weight of all elements }\end{array}$ & $\begin{array}{l}\qquad \tau_{\text {det }}=\frac{\sum_{i=1}^{n} P_{\text {det }(\text { limit })}}{P_{o b j}} \\
\text { nents and engineering systems (s } \\
\text { nstruction or engineering system } \\
\text { uilding, } \% \text {. }\end{array}$ & $\begin{array}{l}\text { 1-37, UPVS), the wear exceeds the } \\
\text { N 53-86(R)), \%; }\end{array}$ \\
\hline
\end{tabular}

Fig.1. Block diagram of determining degree of deterioration

For the selection of the optimal set of repair and restoration measures, it is proposed to determine the degree of deterioration $\left(\tau_{\text {det }}\right)$ of the building according to the specific weight $\left(\mathrm{P}_{\text {det(limit) }}\right)$ of worn out items whose deterioration exceeds allowable values, relative to the total specific weight of the building as a whole $\left(\mathrm{P}_{\mathrm{obj}}\right)$. According to this indicator, there are four categories in terms of the degree of deterioration of the building (Table 2):

1. when $\tau_{\mathrm{det}}<0,05$ - normal condition;

2. when $0,05<\tau_{\operatorname{det}}<0,25$ - satisfactory condition;

3. when $0,25<\tau_{\operatorname{det}}<0,5$ - unsatisfactory condition;

4. when $\tau_{\operatorname{det}}>0,5$ - dilapidated or emergency condition

Objects of cultural heritage require a special research methodology that differs from engineering techniques due to specific art content, as the volume and place of historically and culturally important inclusions and architectural elements should be ascertained. The main thing is the decision of the question, what objects, elements have a historical and cultural value, what is their uniqueness. Accounting for the whole variety of factors that affect the increase in physical depreciation can give a more accurate assessment of its technical condition and making a decision on the need for repair and recovery measures. 
Table 2. Classification of categories of the technical condition of buildings according to the degree of deterioration

\begin{tabular}{|c|c|c|c|}
\hline $\begin{array}{l}\text { Degree of } \\
\text { deterioration }\end{array}$ & $\begin{array}{l}\text { General characteristics of the technical condition of } \\
\text { the building }\end{array}$ & $\begin{array}{l}\text { Recommendations for the elimination } \\
\text { of deterioration }\end{array}$ & $\begin{array}{l}\text { Build } \\
\text { ing } \\
\text { categ } \\
\text { ory } \\
\text { by } \\
\text { bori }\end{array}$ \\
\hline $\begin{array}{l}\text { normal } \\
\text { condition } \tau_{\mathrm{det}} \\
\leq 0,05\end{array}$ & $\begin{array}{l}\text { Malfunctions of the main elements of the building, } \\
\text { improvement and engineering networks are absent. } \\
\text { There are minor damages to individual building } \\
\text { elements. }\end{array}$ & Planned maintenance activities & $\mathrm{I}$ \\
\hline $\begin{array}{l}\text { satisfactory } \\
\text { condition } \\
0,05< \\
\tau_{\text {det }} \leq 0,25\end{array}$ & $\begin{array}{l}\text { Malfunctions of the main building elements, } \\
\text { improvement and engineering networks are } \\
\text { insignificant. The operation of objects is possible with } \\
\text { restrictions. }\end{array}$ & $\begin{array}{l}\text { For maintenance of normal operation } \\
\text { repair operations with a partial } \\
\text { replacement of all faulty elements of a } \\
\text { building are necessary }\end{array}$ & II \\
\hline $\begin{array}{l}\text { unsatisfactor } \\
\text { y condition } \\
0,25<\tau_{\operatorname{det}} \\
\leq 0,5\end{array}$ & $\begin{array}{l}\text { The main building elements, landscaping and } \\
\text { engineering networks have significant malfunctions in } \\
\text { their mass distribution. The operation of the building } \\
\text { must be stopped immediately. }\end{array}$ & $\begin{array}{l}\text { A complete replacement of all } \\
\text { defective building elements is required }\end{array}$ & III \\
\hline $\begin{array}{l}\text { dilapidated or } \\
\text { emergency } \\
\text { condition } \\
\tau_{\text {det }}>0,5\end{array}$ & $\begin{array}{l}\text { The main building elements, landscaping and } \\
\text { engineering networks are not capable of performing the } \\
\text { specified functions. The operation of the facilities must } \\
\text { be stopped. Provides security and maintenance and } \\
\text { conservation activities. }\end{array}$ & $\begin{array}{l}\text { Complex renovation, restoration of } \\
\text { deteriorated and lost building } \\
\text { elements, complete replacement of } \\
\text { engineering equipment, outdoor } \\
\text { communications and amenities }\end{array}$ & IV \\
\hline
\end{tabular}

For a comprehensive assessment of the physical wear of the object $\left(P D_{o b j}\right)$, the following relationship is proposed:

$$
\begin{gathered}
P D_{o b j}=\sum_{i=1}^{n} P D_{I X}\left[f_{i}(t)\right]+P D_{C P}\left[f_{j}(t)\right]+P D_{\mathrm{A}}\left[f_{k}(t)\right]+P D_{E}\left[f_{l}(t)\right]+ \\
P D_{D E}\left[f_{m}(t)\right]+P D_{R R}\left[f_{n}(t)\right],
\end{gathered}
$$

where $\mathrm{PD}_{\mathrm{IX}}$ - deterioration caused by destabilizing factors of internal and external influences on the object;

$\mathrm{PD}_{\mathrm{CP}}$ - the same, under the influence of factors of catastrophic processes;

$\mathrm{PD}_{\mathrm{A}}$ - the same, under the influence of factors of anthropogenic influences (vandalism);

$\mathrm{PD}_{\mathrm{E}}$ - the same, under the influence of environmental factors of the environment;

$\mathrm{PD}_{\mathrm{DE}}$ - the same, under the influence of destabilizing factors, depending on the duration of existence of objects (fatigue, natural aging, etc.);

$\mathrm{PD}_{\mathrm{RR}}$ - the same, under the influence of factors of control actions (reduction due to carrying out repair and restoration measures);

$f_{i, j, k, l, m, n}(t)$ - functional dependence of changes in factors affecting the characteristics of the object, measured by quantitative, qualitative and nominal indicators;

$\mathrm{n}$ - number of objects.

\section{Value approach to the formation of a mechanism for the renovation of cultural heritage objects}

Currently, there are various approaches to determining the significance of the criteria for the value of the object (the methods of L.I. Pavlova, V.I. Lukov, etc.) [16]. The proposed integrated approach is reduced to the distribution of objects by groups of categories of value. 
An integrated approach helps to establish the integral value of objects and identify the main factors of value and the most important evaluation criteria.

a) Historical and archaeological factor

At the heart of the historical evaluation of the object are two principles: the priority of construction time; the importance of the elements of the building as belonging to a particular style epoch. If elements and components of the past, environment objects, fix images in memory of people associated with them, then the memorial component of the value of the object also increases. Some of their elements are carriers of information about the past: events, periods, people. Thus, the historical significance of the object is to reveal the historical authenticity of the building elements, through the determination of the availability of material evidence of their significance, and also to compare the modern appearance of the building with the data of archival research $[3,12]$.

\section{b) Landscape factor}

The landscape factor determines the value of the environment of the object, the components of the landscape, its connection with the natural environment: the presence of water surfaces, green massifs, the formation of the silhouette of the building. Due to the fact that landscape components play an important role in organizing the spatial planning structure of the urban environment, special attention is required by the processes of their renovation. In connection with the intensive processes of transformation of the urban environment, cardinal changes took place in the urban landscape, leading to the almost complete disappearance of the historical landscape. However, renovation processes make it possible to restore especially valuable lost landscape elements [4,9].

\section{c) Functional and economic factor}

The factor of functional value is determined by the need to involve historically significant objects in the modern life of the city with a change in functional purpose, as well as to find the best ways of this involvement related to their possible new functioning, and to link this usage with the architectural and building environment. Criteria of functional value are represented in the following form: originally given functions of the object, the possibility and expediency of renovating the building for modern functions. Functional and economic value is also determined by the proximity to transport highways, metro stations and other types of land and underground transport, the availability of parking lots and intercepting parking facilities, the degree of equipping with engineering systems [15].

\section{d) Architectural and planning factor}

In modern market conditions the architectural and planning factor of the object's value is perceived through the convenience of organizing the internal space of premises and the preferences of people to be in a particular building or room. The architectural value of a building is not a consequence of its technical, constructive or ergonomic qualities, it more characterizes the attitude of a person to a given object $[7,8]$.

\section{e) Environmental factor}

Characterizes the ecological state of the territory on which the object is located, the assessment of potential hazards, industrial production in the impact zone, the forecast of changes in the ecological status of the territory. It includes analysis and assessment of the following criteria: the state of the surface layers of the atmosphere, the cover of the soil, the water surface of reservoirs, the level of noise impact, the probability and degree of destructive effects in a given territory $[13,14]$.

\section{f) Prestigiousness of location}

The prestige factor of location is the most significant and significant in determining the value of the object. The high assessment of this factor is influenced by the presence of trade, administrative and business centers and cultural objects; availability of places of employment; availability of recreational facilities and rehabilitation; availability of nearby housing. The task of assessing the value of an object of cultural heritage is reduced to the 
formation of a factor space containing the distribution of the object by groups of factors that determine its value [16]. Thus, a system of factors and criteria is built up - a model that reflects the uniqueness of the characteristics of the building as a unique object of cultural heritage with a certain level of value (Table 3 ).

Table 3. Classification scheme of factorial and criterion space for assessing the value of cultural heritage

\begin{tabular}{|c|c|c|c|c|c|}
\hline $\begin{array}{c}\text { historical- } \\
\text { archaeological }\end{array}$ & landscape & $\begin{array}{l}\text { functional- } \\
\text { economic }\end{array}$ & $\begin{array}{l}\text { prestige } \\
\text { location }\end{array}$ & $\begin{array}{c}\text { architectural } \\
\text { planning }\end{array}$ & environmental \\
\hline $\begin{array}{l}\text { combination of the } \\
\text { historically significant } \\
\text { elements of various } \\
\text { styles } \\
\text { Y11 }\end{array}$ & $\begin{array}{l}\text { role of the main } \\
\text { dominants in the } \\
\text { spatial } \\
\text { composition of } \\
\text { the city } \\
\text { Y21 }\end{array}$ & $\begin{array}{c}\text { proximity to } \\
\text { highways, metro } \\
\text { stations and public } \\
\text { transport stops } \\
\text { Y31 }\end{array}$ & \multirow{2}{*}{$\begin{array}{c}\text { presence of } \\
\text { commercial, } \\
\text { administrative and } \\
\text { business cents and } \\
\text { structures of } \\
\text { culture } \\
\text { Y41 }\end{array}$} & $\begin{array}{c}\text { preservation planning } \\
\text { scheme of the } \\
\text { territory } \\
\text { Y51 }\end{array}$ & $\begin{array}{l}\text { condition of the } \\
\text { surface layers of the } \\
\text { atmosphere } \\
\text { Y61 }\end{array}$ \\
\hline $\begin{array}{l}\text { historic preservation } \\
\text { plan for the area } \\
\text { Y12 }\end{array}$ & $\begin{array}{l}\text { safety of the } \\
\text { silhouette of the } \\
\text { building } \\
\text { Y22 }\end{array}$ & $\begin{array}{c}\text { presence of parking } \\
\text { lots } \\
\text { Y32 }\end{array}$ & & $\begin{array}{c}\text { accessory building to } \\
\text { a significant } \\
\text { architectural era } \\
\text { Y52 }\end{array}$ & $\begin{array}{c}\text { condition of the cover } \\
\text { soil } \\
\text { Y62 }\end{array}$ \\
\hline $\begin{array}{c}\text { predominance of } \\
\text { authentic historical } \\
\text { pieces and } \\
\text { architectural details } \\
\text { Y13 }\end{array}$ & $\begin{array}{c}\text { historical } \\
\text { authenticity of the } \\
\text { site } \\
\text { Y23 }\end{array}$ & $\begin{array}{l}\text { situation with access } \\
\text { roads: the } \\
\text { construction of new } \\
\text { and reconstruction } \\
\text { of existing } \\
\text { Y33 }\end{array}$ & $\begin{array}{l}\text { availability of } \\
\text { recreation and } \\
\text { rehabilitation } \\
\text { Y42 }\end{array}$ & $\begin{array}{l}\text { stylistic unity and } \\
\text { integrity of the } \\
\text { territory and } \\
\text { development } \\
\text { Y53 }\end{array}$ & $\begin{array}{l}\text { vulnerability of the } \\
\text { territory to the } \\
\text { destructive effects } \\
\text { Y63 }\end{array}$ \\
\hline $\begin{array}{l}\text { connection of the } \\
\text { place with a historical } \\
\text { period, event, an } \\
\text { outstanding figure of } \\
\text { the past } \\
\text { Y14 }\end{array}$ & $\begin{array}{c}\text { presence of water } \\
\text { surfaces } \\
\text { Y24 }\end{array}$ & \multirow{2}{*}{$\begin{array}{c}\text { degree of } \\
\text { arrangement of } \\
\text { engineering systems, } \\
\text { construction of new } \\
\text { and reconstruction } \\
\text { of existing } \\
\text { engineering } \\
\text { networks } \\
\text { Y34 }\end{array}$} & $\begin{array}{c}\text { presence of nearby } \\
\text { housing } \\
\text { Y43 }\end{array}$ & $\begin{array}{l}\text { possibility of adapting } \\
\text { to modern needs and } \\
\text { change of the } \\
\text { functional purpose of } \\
\text { the territory } \\
\text { Y54 }\end{array}$ & $\begin{array}{l}\text { level of impact from } \\
\text { noise, industrial } \\
\text { facilities } \\
\text { Y64 }\end{array}$ \\
\hline $\begin{array}{c}\text { one of a kind, unique } \\
\text { territory } \\
\text { Y15 }\end{array}$ & $\begin{array}{c}\text { presence of green } \\
\text { spaces } \\
\text { Y25 }\end{array}$ & & $\begin{array}{c}\text { Availability of jobs } \\
\text { Y44 }\end{array}$ & $\begin{array}{c}\text { proximity of the } \\
\text { historical monuments } \\
\text { Y55 }\end{array}$ & $\begin{array}{c}\text { condition of water } \\
\text { surface reservoirs } \\
\text { Y65 }\end{array}$ \\
\hline
\end{tabular}

The integral value of an object can be calculated by the following formula:

$$
C_{o b j}=\sum_{i=1}^{m} \sum_{j=1}^{n} Y_{i j} * w_{i}
$$

where $\mathrm{C}_{\mathrm{obj}}$ - ценность объекта в баллах;

$Y_{i j}$ - score in points (weight of the criterion in fractions of a unit) of the j-th index of the i-th criterion;

$n$ - number of indicators of the $\mathrm{j}$-th criterion;

$w_{j}$ - the weight of the i-th factor;

$m$ - number of factors;

$i$ - indicator of estimation of the $\mathrm{j}$-th criterion;

$j-$ criterion.

The total value of the object is determined by the total indicator of the value of all the criteria considered in the assessed system, expressed in one hundred point scale, i.e. $C_{o b j}=$ $\sum_{k=1}^{n} Y_{i j} * 100$, where $Y_{i j}$ is the significance of the value criterion, $k=1 . . n$ is the number of criteria for the value of the object under consideration [10].

When solving the set task of forming a rational set of monument buildings that are to be preserved according to the highest value indicator, with minimal indicators of physical deterioration, by direct selection and evaluation of the most effective option from all possible, a large number of factors must be taken into account. In connection with this, the solution of the problem under consideration by searching and evaluating all possible variants under real 
conditions is practically not acceptable because of the large dimensionality of the problem being solved [17]. Therefore, another approach to its solution has been developed.

The analysis shows that its solution can be based on determining the ratio of the value of each object under consideration and the extent of its deterioration at the time of repair and recovery activities with their subsequent ranking, i.e. the solution can be made based on the $\mathrm{C}_{\mathrm{obj}} / \tau_{\text {det }}$ relations. We find such relations for all the objects under consideration and form their series in ascending order, i.e. formed series of:

$$
\mathrm{C}_{1} / \tau_{1} \geq \mathrm{C}_{2} / \tau_{2} \geq \mathrm{C}_{3} / \tau_{3} \geq \ldots \geq \mathrm{C}_{\mathrm{i}} / \tau_{\mathrm{i}} \geq \ldots \geq \mathrm{C}_{\mathrm{k}} / \tau_{\mathrm{k}}
$$

Then a selection of objects is made from the formed series, beginning with the first one, which has the maximum value index at the minimum values of the wear rate of the object itself. Thus, it will probably be most efficient to select the objects that are subject to repair and restoration measures within the framework of a specific state program for the preservation of cultural heritage sites. As a result of applying the proposed methodology, it is possible to obtain an optimal set of objects that provides the maximum total value when they are renovated.

The objective function of the formation of a state program for the renovation and preservation of cultural heritage objects should be to find such values of the indicators when, under existing restrictions, the total physical deterioration throughout the totality of the objects will be the smallest, while achieving the maximum degree of preservation of the value of cultural heritage objects. The mechanism for choosing the best option is presented in the form of the following organizational-mathematical model:

$$
\left\{\begin{array}{l}
\sum_{i=1}^{n} P D_{o b j} \Rightarrow \min \\
\sum_{j=1}^{m} \frac{C_{o b j}}{\tau_{d e t}} \Rightarrow \max
\end{array},\right.
$$

where $P D_{o b j}$ - cumulative physical deterioration,

$C_{o b j}$ - integral indicator of the value of the object,

$\tau_{\text {det }}-$ deterioration rate of the object.

\section{Results and discussion}

Thus, when solving the problems of increasing the effectiveness of the state programs for the preservation of cultural heritage objects, it is necessary to focus on the systematization and comprehensive assessment of the technical condition of especially valuable objects by creating specialized restoration centers at the state level, allocating budgetary funds for financing, and training skilled personnel for this type of activity. State programs for the preservation and renovation of cultural heritage should not be periodic, but systemic in nature, cover all areas of this particular type of activity, and most effectively create a database of preserved objects [18].

State registration of objects of cultural heritage should become a fundamental direction in the field of protection of monuments of historical heritage of large cities. At present, the main task in the sphere of state registration of cultural heritage objects can be called the formation of a single register of objects of cultural heritage (historical and cultural monuments) of the Russian Federation. The formation of a detailed information base of such objects will allow to have a more complete view for the prospects of forecasting the volumes of repair and restoration measures and maintaining a satisfactory technical condition of the objects. However, objectively arises the problem of prioritization in the formation of objects subject to priority measures for monitoring the technical condition, since the number of monuments of historical heritage is quite large with limited financial resources allocated for the implementation of renovation programs, in connection with which the solution of this problem is the most urgent problem for today day. 


\section{Conclusion}

The article reveals the main problems associated with the preservation of monuments of historical heritage, whose technical condition survey has a periodic character and there is no permanent system for monitoring their condition. Effective ways of solution are offered at formation of the state programs of preservation of objects of a cultural heritage by creation of a technique of optimum selection of objects for carrying out of repair-restoration actions. The key tasks of the developed methodology and a set of its optimal components are considered [20]. The proposed methodology for calculating the ratio of the integral indicators of the value of the object and the degree of its wear and tear will make it possible to select the necessary number of objects that need repair and recovery measures most efficiently. Thus, at the level of state programs for preserving the historical heritage, it is possible to achieve optimal timely solutions for renovating such facilities, providing optimal options for their stable and reliable operation.

\section{References}

1. M. Rabbani, N. Poumohammad, H. Rafiei, Applied Mathematics and Computation 5, 149-160 (2016)

2. I. Malegiannaki, T. Daradoumis, Computers \& Education 108,1-10 (2017)

3. P.C. Guzmán, A.R. Pereira Roders, B.J.F. Colenbrander, Cities 60, 192-201 (2017)

4. M. Peniüa, Procedia Engineering 117,883-890 (2015)

5. A.A. Kuzmichev, V.F. Loboyko, Procedia Engineering 150, 2095-2101 (2016)

6. V.A. Stolbova, L.I. Pavlova, Real Estate: Economics 2, 76-84 (2015)

7. E.Z. Kordatos, D.A. Exarchos, C. Stavrakos, A. Moropoulou, T.E. Matikas, Construction and Building Materials 48, 1261-1265(2013)

8. F. Amato, F. Martellozzo, G. Nolè, B. Murgante, Journal of Cultural Heritage 23, 44-54 (2017)

9. M. Andretta, F. Coppola, A. Modelli, N .Santopuoli, L. Seccia, Journal of Cultural Heritage 23, 22-32 (2017)

10. L.I. Pavlova, Real Estate: Economics 3-4, 15-20 (2014)

11. I. Kuznetsova, D. Kuznetsova, X. Rakova, Procedia Engineering 100, 1625-1633 (2015)

12. G. Sabatini, M. Giamello, R. Pini, S. Siano, R. Salimbeni, Journal of Cultural Heritage 1, 9-19 (2000)

13. T.P.Cooper, Technology and European Cultural Heritage, 465-468 (1991)

14. R.Vicente, T. M. Ferreira, J.A. Raimundo, M. da Silva, Journal of Cultural Heritage 16, 1-14 (2015)

15. Grabovy P.G., Naumov A.E., Avilova I.P, International Business Management 10, 1354-1364 (2016)

16. L.I. Pavlova, I.S. Sychev, Real Estate: Economics 1, 67-70 (2012)

17. V.A. Stolbova, Scientific-technical journal of Volga region 5, 252-255 (2011)

18. S. Beliakov, A. Kapustkina, Procedia Engineering 165, 1424-1429 (2016)

19. O. Kurakova, N.Khomyak, Procedia Engineering 165, 1221-1228 (2016)

20. B.V. Prykin, L.V. Prykina, O.A Manukhina, Real Estate: Economics 1, 18-22 (2016) 